\title{
INFLUENCE OF UNDERWATER HYDRODYNAMICS ON OIL AND GAS BLOWOUTS OFF AMAZON RIVER MOUTH
}

\author{
Humberto L. VARONA ${ }^{1,2 *}$; Marcus A. SILVA ${ }^{1,2}$; Dóris VELEDA ${ }^{1,2}$; Fabiana S. LEITE ${ }^{1,2}$; Márcio das \\ Chagas MOURA ${ }^{3}$; Moacyr ARAUJO ${ }^{1,2}$
}

\begin{abstract}
${ }^{1}$ Department of Oceanography, DOCEAN, Federal University of Pernambuco, Recife, PE, Brazil. E-mail: humberto.varona@yandex.com, marcus.oceano@gmail.com, doris.veleda@ufpe.br, fasoaresl@yahoo.ca, moa.ufpe@gmail.com

*Autor correspondente
\end{abstract}

${ }^{2}$ Center for Risk Analysis and Environmental Modeling - CEERMA. Federal University of Pernambuco, Recife, PE, Brazil.

${ }^{3}$ Department of Production Engineering, Federal University of Pernambuco, Recife, PE, Brazil. E-mail: marcio@ceerma.org

\begin{abstract}
RESUMO. O estudo está focado na análise do comportamento das plumas de vazamento de óleo/gás em águas profundas, localizadas na plataforma continental do norte do Brasil. O modelo Regional Ocean Modeling System (ROMS) é utilizado para simular a dinâmica oceânica na região $60.5^{\circ}-24^{\circ} \mathrm{W} / 5^{\circ} \mathrm{S}-16^{\circ} \mathrm{N}$ com $0.25^{\circ}$ de resolução, 32 níveis verticais e considerando as descargas dos rios Amazonas e Pará. A saída do modelo ROMS é comparada com o conjunto de dados SODA (Simple Ocean Data Assimilation). Três pontos foram selecionados para fazer as simulações numéricas, localizados em $\left(50^{\circ} \mathrm{W}, 5.25^{\circ} \mathrm{N}\right)$, $\left(44.5^{\circ} \mathrm{W}, 0.5^{\circ} \mathrm{N}\right)$ e $\left(42.75^{\circ} \mathrm{W}, 1^{\circ} \mathrm{S}\right)$. O passo do tempo sugerido por Lee e Cheung (1990) foi ajustado devido às condições oceanográficas particulares em cada ponto, em que a velocidade inicial tende a zero. O coeficiente 0.1 da equação original foi substituído por 0.0250 e 0.0375 . Todas as plumas se comportaram como tipo 3. A velocidade de corrente sazonal foi pequena do fundo á superfície, não excedendo $0.25 \mathrm{~ms}^{-1}$; o deslocamento máximo das plumas de seu ponto de origem não foi maior do que $1 \mathrm{~m}$. O diâmetro médio das plumas na superfície variou de 54 a $79.7 \mathrm{~m}$ e o tempo de chegada à superfície foi de 7.25 a 8.05 horas.
\end{abstract}

Palavras-Chave: Vazamento de Óleo/Gás, Foz do Rio Amazonas, Oceano Atlântico, Modelo ROMS, Modelo GAS_DOCEAN.

\begin{abstract}
This study is focused on analyzing the behavior of oil/gas plumes from blowouts into deepwater, located at the northern Brazil continental shelf. The Regional Ocean Modeling System (ROMS) model is used to simulate ocean dynamics in the region $60.5^{\circ}-24.0^{\circ} \mathrm{W} / 5^{\circ} \mathrm{S}-16^{\circ} \mathrm{N}$ with $0.25^{\circ}$ of resolution, 32 vertical levels and considering the discharges of the Amazon and Pará Rivers. The ROMS output are compared to Simple Ocean Data Assimilation (SODA) dataset. Three points were selected to make the numerical simulations, located at $\left(50^{\circ} \mathrm{W}, 5.25^{\circ} \mathrm{N}\right),\left(44.5^{\circ} \mathrm{W}, 0.5^{\circ} \mathrm{N}\right)$ and $\left(42.75^{\circ} \mathrm{W}, 1^{\circ} \mathrm{S}\right)$. The time step suggested by Lee and Cheung (1990) was adjusted due to the particular oceanographic conditions at each point, in which, the initial velocity tends to zero and the coefficient 0.1 of the original equation was replaced by 0.0250 and 0.0375 . All the plumes behaved as type 3 . The seasonal current speed was small from the bottom to the surface, usually not exceeding $0.25 \mathrm{~ms}^{-1}$; the maximum displacement of the plumes from its point of origin was not greater than $1 \mathrm{~m}$. The mean plumes diameter on the surface ranged $54-79.7 \mathrm{~m}$ and the arrival time to the surface was from 7.25 to 8.05 hours.
\end{abstract}

Keywords: Oil/Gas Blowouts, Amazon River mouth, Atlantic Ocean, ROMS model, GAS_DOCEAN model. 


\section{INTRODUCTION}

The dependence of industry and life with the use of oil and gas is very significant; the demand for these two products and their derivatives is extremely high (IEA, 2009; EIA, 2011; Lara, 2014; Prates et al., 2006). Large oil and gas extraction corporations are increasingly expanding into new areas, exploring and exploiting more and more natural gas and oil reserves in the deep ocean. These exploration and exploitation processes are subject to risk of accidents (O'Rourke and Connolly, 2003; Skogdalen et al., 2011), which can endanger human life and contaminate the ocean and the littoral.

The exploration and production of oil at sea is a risk-filled activity (Skogdalen and Vinnem, 2012; Small et al., 2014), as well its research (Abimbola et al., 2014; Neff et al., 1987). It requires dangerous tasks such as drilling rocks in ultra-deep regions, facing very high pressures and handling large volumes of oil and gas. This activity analyzes the large volume of information generated in the initial stages of the investigation, gathering a reasonable knowledge about the depth, thickness and behavior of existing rock layers in a sedimentary basin and the hydrodynamics of the region. Based on this knowledge, the best places to drill in the basin are chosen.

In recent decades, the environmental impacts of oil spills have occurred throughout the world and marine flora and fauna have been frequently submitted to environmental impacts caused by these events (Teal and Howarth, 1984; Ugochukwu and Ertel, 2008). Contamination of marine and coastal environments by oil has been a concern for environmentalists around the world (Mendelssohn et al., 2012). Oil residues and by-products can cause serious consequences for human life (Charrouf and Guillaume, 2008), coastal ecosystems and socioeconomic activities (de Andrade et al., 2010), and has been the subject of many debates. This type of impact causes real environmental catastrophes, with incalculable and often irreversible damage to the environment. Human activities, such as fishing and tourism are also compromised (Garza-Gil et al., 2006), causing great economic damages.

Finally, there has been a progressive decrease in the number of accidents and in the volume of oil discharged internationally (ITOPF, 2016). The reduction of accidents is associated with greater control and care in operations involving the exploration, exploitation, transport and storage of oil, which reflects an increase in the level of environmental responsibility of the society.

Environmental sensitivity to oil spills has been studied some decades ago by Gundlach and Hayes (1978). These authors constructed sensitivity maps containing three types of spatial information: the classification of the sensitivity of environments, biological resources and human resources of recreational, subsistence or commercial value. Thus, the classification of 
the environment is made according to its physical characteristics, oil permanence and conditions of cleaning and removal.

The Environmental Sensitivity Charts to Oil Spills are essential tools and a primary source of information for contingency planning and for the implementation of response actions to oil pollution incidents, allowing the identification of environments with protection priority and possible areas of sacrifice, allowing the correct allocation of resources and the proper mobilization of containment and cleaning equipment (Carvalho and Gherardi, 2003; Michel et al., 1978).

The impacts of an oil spill and blowout can be minimized if locations most sensitive to contact with the oil can be protected. The previous knowledge of oil spills and explosions under the sea can help in the distribution of available resources to give a more effective response to these types of accidents. The understanding of oceanographic processes in the oil and gas blowouts is fundamental for its prevention and mitigation. In case of oil and gas blowouts, companies would have contingency planning and mitigation to reduce the impact on the environment.

The increase of the oil and gas production in marine environment verified above all in the mid-year 2000 (E\&P Forum/UNEP, 1997; U.S. DOE, 1999; U.S. EIA, 1998; U.S. NOIA, 2005) brought the need of more precise models for evaluation of the transport and dispersion of these mixtures in the oceans, as well as their effects on the environment. Initially, Fannelop and Sjoen (1980) focused on the case of the evolution of a single gas plume in the ocean. These authors proposed an approach of simplified analytical modeling, with non-dimensional solutions, and applicable in cases of spills in shallow waters. In this model, the gas expansion all through the water column was estimated considering the classical theory of ideal gas. As a result, the solution for this model brings the dimensions of the cone of gas formed along the water column (starting from the ocean floor), and in consequence, the diameter of the gas plume in the surface.

Meanwhile, the Fannelop and Sjoen (1980) approach does not consider horizontal advection of gas through the currents. Some advance on this initial idea was proposed by Friedl and Fanneløp (2000), when routines were added that considered the elevation in the surface of the sea provoked by the reaching of the gas to the surface (fountain effect, Fig. 1 in Friedl and Fanneløp (2000)). In deeper waters, for instance, the gas cannot be treated as an ideal mixture (Chen and Yapa, 2001), and new interaction processes among the two means gas and liquid was observed, mainly when the local pressure is very different to the atmospheric pressure. In this new generation of mathematical models, created to represent simultaneously oil and gas plumes in marine environment, two more important physiochemical processes were considered, formation of gas hydrate (Chen and Yapa, 2001; Topham, 1984) and gas dissolution (Johansen, 
2003; Zheng and Yapa, 2002) in seawater. In shallow waters, the gas dissolution is neglectable (Johansen, 2000).

However, in deep waters, the travel time for the gas through the water column is longer, also rising the dysphasic flow time. Adding to this the fact that the gas solubility increases with the environmental pressure (Johansen, 2000), it is observed frequently that under natural conditions of low temperature and high pressure. The gas tends to form hydrates, which significantly change the ascension velocity of the gaseous plume along the water column (Chen and Yapa, 2001; Johansen, 2003; Topham, 1984). The first models plume evolution of gas developed did not foresee in their equations these two mechanisms (dissolution and hydration), limiting itself to its application in deeper ocean areas (Chen and Yapa, 2001). Yapa and Zheng (1997), for instance, proposed a set of equations to predict the space-time evolution of plumes formed by spills in intermediate waters, considering only the advective transport of the gas as function of its characteristics (volumetric composition) and the environmental thermodynamic conditions (temperature fields, salinity, pressure and density). In the 90's these important mechanisms were introduced into the modeling of a plume of gas in the marine environment (Chen and Yapa, 2001; Reed et al., 1999; Yapa et al., 2001; Zheng and Yapa, 2000).

In this work will be analyzed the dilution capacity of the oil/gas effluents overflow in a blowout event as a result of the simultaneous effects of sea currents, winds and surface and subsurface thermodynamic processes. Three different locations were selected at the continental shelf of Brazil, near the Amazon River mouth and adjacent oceanic areas. This analysis will be held through mathematical modeling of hydrodynamics and gas/oil dispersion plumes in the study region.

\section{STUDY AREA}

The Amazon Continental Shelf is a high priority area for the conservation of biodiversity (dos Santos et al., 2016; da Silva Junior and Magrini, 2014) and the Amazon River mouth represents the limit of the distribution of several sponges, lobster, stony corals and snapper and others shallow water fishes, among other groups of coastal and reef organisms (Moura et al., 2016). Our region of study is framed in $52^{\circ}-40^{\circ} \mathrm{W} / 4^{\circ} \mathrm{S}-10^{\circ} \mathrm{N}$ with $0.25^{\circ}$ of resolution, covering an area of $9464500 \mathrm{~km} 2$. Fig. 1 shows the bathymetry with the positioning of points P1, P2 and P3 over the continental shelf in the northern coast of Brazil and the location of the deepwater oil exploration blocks. 


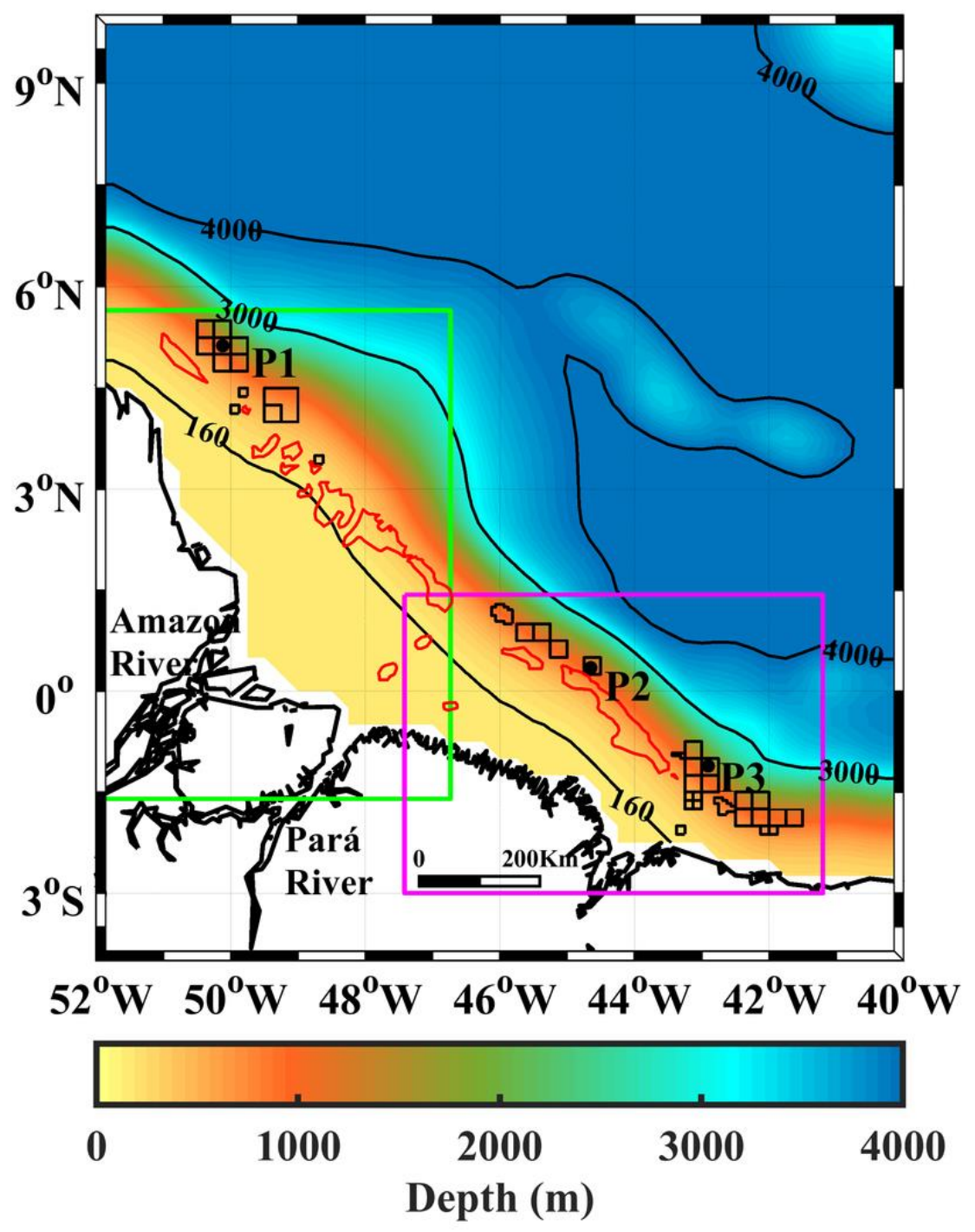

Figure 1. The bathymetry and distribution of the slope in the continental shelf off northern Brazil are represented the isobaths of 160,3000 and $4000 \mathrm{~m}$ in black continuous lines. The green rectangle represents the Amazon mouth basin and the magenta one represents Pará-Maranhão-Barreirinhas basin. The oil and gas exploration blocks are represented by black polygons. The location of P1, P2 and P3 is represented by blue points above of exploration blocks where P1, P2 and P3 are placed - block FZA-M-88 (P1), block PAMA-M-337 (P2) and block BAR-M-21 (P3). The coral reef appears in red color.

The most important oceanic currents around the Amazon region are North Brazil Current (NBC), North Equatorial Countercurrent (NECC) and South Equatorial Current (SEC). According to Stramma and England (1999) the SEC is divided into four branches: the Southern South Equatorial Current (SSEC), the Central South Equatorial Current (CSEC), the northern South Equatorial Current (nSEC) and equatorial South Equatorial Current (eSEC). The eSEC and cSEC give origin to NBC; the latter is also fed by nSEC. At each season the SEC has a strong flow the 
westwards (about $0.3 \mathrm{~ms}^{-1}$ ) near the equator and weaker $\left(0.1-0.15 \mathrm{~ms}^{-1}\right.$ ) in a broad band south of $10^{\circ} \mathrm{S}$ (Peterson and Stramma, 1991).

NBC flows from northwestward (Lentz, 1995) along the northeastern continental margin of Brazil as a coastal current developing an retroflexion in rings form (Dessier and Donguy, 1994; Fratantoni et al., 1995; Goes et al., 2005; Johns et al., 1990; da Silveira et al., 2000). This makes a turn to the east driven by the wind and feeds the NECC, the NBC reaches speeds of 0.75-1.00 $\mathrm{ms}^{-1}$ (Arnault et al., 1999). During the summer, in response to a shift towards the north of the trade winds, the NECC forms eastwards, intensifying significantly during the winter (Grodsky and Carton, 2002; Richardson and Walsh, 1986). The NECC is located between 3$10^{\circ} \mathrm{S}$ and is considered as the northern boundary for SEC (Peterson and Stramma, 1991). The nSEC is a water source that reinforces the NECC (Stramma and England, 1999). The northern limit of NECC when present is the North Equatorial Current (NEC). The mean speed eastward of NECC is $0.42 \mathrm{~ms}^{-1}$ (Fratantoni, 2001).

\section{THE REGIONAL OCEAN MODELING SYSTEM (ROMS)}

The ROMS model was used to reproduce climatological and spatial-time variability of oceanic circulation and thermohaline variability in the study area. ROMS is an open source programming, which is effectively created by an extensive group of engineers and researchers, with more than 400000 lines of FORTRAN code, coordinating primitive conditions in a rotational arrangement of free surface, utilizing the Boussinesq approximation, the hydrostatic guess and the adjust of the vertical force (Panzer et al., 2013; Shchepetkin and McWilliams, 2005; Song and Haidvogel, 1994). This was adjusted to various geographic areas of the world where great outcomes were gotten (Haidvogel et al., 2000; Penven et al., 2000; Silva et al., 2009).

The area used for the ROMS model simulations is framed in $60.5^{\circ}-14.5^{\circ} \mathrm{W} / 15.5^{\circ} \mathrm{S}-24.5^{\circ} \mathrm{N}$. The bathymetry grid has $183 \times 159$ nodes with 32 levels in the vertical, of which 20 are in the upper 500 m depth. The ETOPO2 (Smith and Sandwell, 1997) topography database was used in the vertical discretization with 2 min of horizontal resolution. The surface forcings were obtained from monthly mean climatology of Comprehensive Ocean Atmosphere Data Set (COADS05) (Da Silva et al., 1994) with $0.5^{\circ}$ of horizontal resolution. Tides are an important process in mixing the river freshwater plumes with the open ocean and are obtained from the TPXO7 (Egbert and Erofeeva, 2002; Egbert et al., 1994), which has altimetry data from several satellites to improve the accuracy of the results obtained through the hydrodynamic model (D'Onofrio et al., 2012; Wang, 2004). All lateral boundaries are considered open. For the lateral boundary and initial conditions all variables were obtained from the monthly mean of World Ocean Atlas 2009 (WOA2009) (Antonov et al., 2010; Locarnini et al., 2010) with horizontal resolution of $1^{\circ}$. The monthly mean river discharge was obtained from Obidos and Tucurui gauge stations (Dai and 
Trenberth, 2002), while the monthly climatology of sea surface temperature (SST) in the rivers discharge points was also obtained from WOA2009.

We have carried out a numerical experiment with ROMS model to characterize the hydrodynamic: salinity, temperature, and currents on the western tropical north Atlantic (WTNA) taking into account the discharges of the Amazon and Pará Rivers. These rivers release freshwater into the WTNA, giving the geographical configuration of Amazon River Delta. There are four inputs from the river to WTNA: Canal do Norte, Baia de Santa Rosa, Canal Perigoso and Canal do Jurupari and they were placed in four cells of the grid. Considering the width of each channel the contribution was calculated for each one with the same monthly temperature distribution for the four inputs nodes in the Amazon River Delta and different in the input node of the Pará River. We run ROMS model for 11 years but our analysis are restrict to the last 3 years of simulation.

The model validation of sea surface salinity (SSS), SST, potential salinity and temperature on the surface was implemented using the Simple Ocean Data Assimilation (SODA) version 2.2.4 (Carton et al., 2000). This dataset presents a spatial resolution of $0.5^{\circ}$ and was used for a period of 20 years (1991 to 2010).

\section{THE GAS_DOCEAN MODEL}

Pollutant dispersion models have been developed to the ocean, combining analytical expressions, Eulerian or Lagrangian formalism (De Dominicis et al., 2013). One of the advantages of these models is their flexibility to assimilate different types of dataset, as the case with the output data of other models, such as the ROMS model (North et al., 2011) or even using in situ current and thermohaline data (Leite et al., 2014).

In this study the evolution of the oil/gas plumes through the water column was estimated based on the theory proposed by Chen and Yapa (2004), Fannelop and Sjoen (1980), Friedl and Fanneløp (2000), Yapa et al., (2001), Zheng and Yapa (1998), Zheng and Yapa (2000) and Zheng and Yapa (2002). These studies were used for the elaboration of computational routines that represent the simultaneous transport of oil and natural gas. This model was previously used by Leite et al. (2014) in the evaluation of natural gas plumes that resulted from an eventual blowout in the oceanic floor. The new implementations to the GAS_DOCEAN code (version 3.0) allow the simulations of simultaneous evolution of the plumes of oil and natural gas. The adopted methodology follows the theoretical-experimental approach proposed by Chen and Yapa (2004).

Hogh pressure and temperature may induce the formation of hydrates starting from lighter hydrocarbon chains (Chen and Yapa, 2004; Zheng and Yapa, 2002). With the formation of hydrates, the upwelling time for the gas along the water column will be incremented, since 
their presence will induce the reduction of ascending velocity of the gas plume (Chen and Yapa, 2001; Johansen, 2003; Topham, 1984). The physical-chemical characteristics of the oil, necessary for simulations, were then calculated from each depth through parameterized equations inserted in the mathematical model, and taken from experimental curves obtained in laboratory.

In order to estimate time step $(\Delta \mathrm{t})$, Lee and Cheung (1990) suggested Eq. 1 and was later used by Dasanayaka and Yapa (2009), Premathilake et al. (2016) and Yapa and Zheng (1997) obtaining good results

$\Delta \mathrm{t}=0.1 \frac{\mathrm{b}_{0}}{\left|\mathrm{~V}_{0}\right|}$

where $\Delta \mathrm{t}$ is time step in $\mathrm{s}, b_{o}$ is ratio of initial control-volume in $\mathrm{m}$ and $V_{o}$ is initial blowout velocity in $\mathrm{ms}^{-1}$.

\section{SCENARIOS FOR THE SIMULATION OF OIL AND GAS PLUMES}

The points P1, P2 and P3 (Fig. 1) were selected according to the position of the oil and gas exploration blocks in the north continental shelf of Brazil and the analysis of oil sensitivity charts (SAO charts) of the areas subject to oil spill and blowouts in the region comprising the continental shelves of Amazon and Pará-Maranhão-Barreirinhas basins. P1 is located at $50^{\circ} \mathrm{W}, 5.25^{\circ} \mathrm{N}$ and belongs to the FZA-M-88 exploration block; $\mathrm{P} 2$ at $44.5^{\circ} \mathrm{W}, 0.5^{\circ} \mathrm{N}$, corresponds to the PAMA-M-337 exploration block and P3 it is located in BAR-M-21 exploration block at $42.75^{\circ} \mathrm{W}, 1^{\circ} \mathrm{S}$ (ANP, 2017). The parameters used in the simulations of oil/gas plumes are those reported by Chen and Yapa (2004) with the exception of those shown in the Tab. 1.

Table 1. Parameterization of GAS_DOCEAN.

\begin{tabular}{lr}
\hline \multicolumn{1}{c}{ Parameters } & Value \\
\hline Ratio between the bubble core & 0.8 \\
width and the buoyant jet diameter & \\
Gas density & $5 \times 10^{-3} \mathrm{~kg} \mathrm{~m}^{-3}$ \\
Initial shear entrainment coefficient & 0.083 \\
Gas flow & $50 \mathrm{~kg} \mathrm{~s}^{-1}$ \\
Oil flow & $100 \mathrm{~kg} \mathrm{~s}^{-1}$ \\
Mass transfer coefficient of dissolution & $10^{-9} \mathrm{~m} \mathrm{~s}^{-1}$ \\
\hline
\end{tabular}


The main variables influencing the behavior of oil spills and blowouts are temperature, salinity and marine currents. The vertical profiles of the speed of the current are corroborated using the SODA dataset, with spatial resolution of $0.25^{\circ}$. Also the average values of the zonal component are compared in region Western North Equatorial Countercurrent (WNECC) framed at $\left(50^{\circ}-40^{\circ} \mathrm{W} / 5^{\circ}-8^{\circ} \mathrm{N}\right)$, whose average values were reported by Richardson and Reverdin (1987).

Fig. 2 depicts that the numerical mean seasonal currents are able to reproduce the advection patterns already reported by many authors (Fratantoni, 2001; Grodsky and Carton, 2002; Haidvogel et al., 2000; Malanotte-Rizzoli et al., 2000), The fundamental actor in the area ins the NBC, which forms large anticyclonic rings shed by the current of the northwestern whirl along the Norte Brazilian continental shelf.

The Amazon plume is transported along the Brazilian continental shelf by the NBC to the northwest during December-January-February (DJF) (Fig. 2), increasing its transportation in the months March-April-May (MAM) and reaching its maximum during June-July-August (JJA) (Muller-Krager et al., 1988; Salisbury et al., 2011). When NBC retroflexion occurs, it is transported eastward by the NECC during the period of September-October-November (SON) (Coles et al., 2013; Foltz et al., 2015; Moon and Song, 2014; Muller-Krager et al., 1988).

The NECC is the main current that transports the Amazon plume eastward. Varona et al. (unpublished data) compared the zonal component ( $u$ ) differences between ROMS model results and Surface Currents from Diagnostic model (Maximenko and Hafner, 2010) in an area associated to the east of the NECC, located at $48^{\circ}-41^{\circ} \mathrm{W} / 2^{\circ}-8^{\circ} \mathrm{N}$ (EPLUME). Concluding that values of $u$ indicate a gradually increasing from $0.2 \mathrm{~ms}^{-1}$ to $0.3 \mathrm{~ms}^{-1}$, from JJA to SON, between $4.5^{\circ}$ and $9.5^{\circ} \mathrm{N}$, finding the maximum bias $\left(0.2 \mathrm{~ms}^{-1}\right)$ between $5.5^{\circ}$ and $6.5^{\circ} \mathrm{N}$ in July and between $4^{\circ}$ and $5^{\circ} \mathrm{N}$ in October. The mean bias is $0.1 \mathrm{~ms}^{-1}$. These results reveal that ROMS model represents quite well the dynamics of the NECC variability. The average of the zonal component in WNECC is $0.384 \mathrm{~ms}^{-1}$ during SON, according to reported by Richardson and Reverdin (1987), being $0.410 \mathrm{~ms}^{-1}$. 


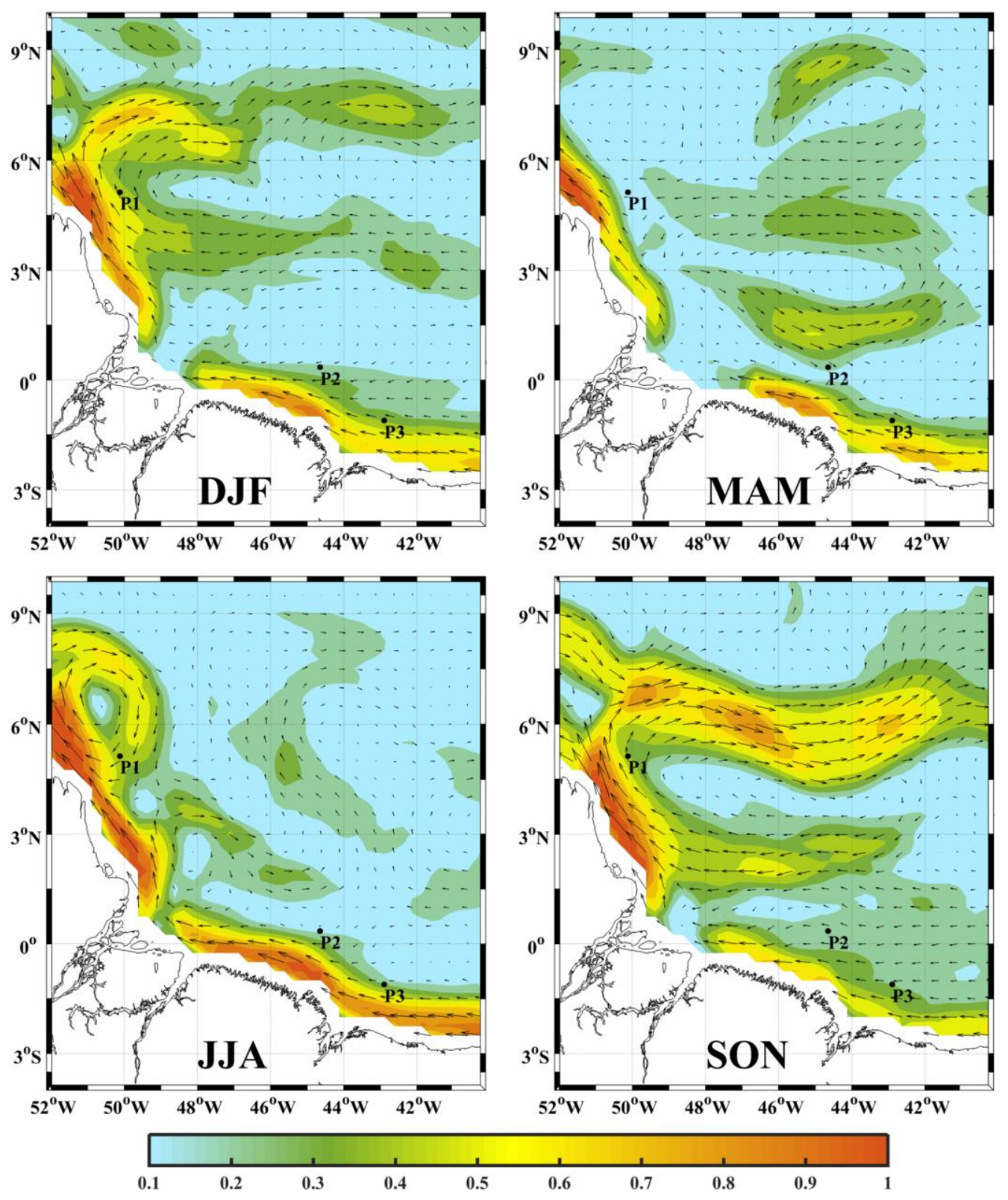

Figure 2. ROMS model outputs of the seasonal marine currents during the boreal winter (DJF-December, January, February), spring (MAM-March, April, May), summer (JJA-June, July, August), and fall (SONSeptember, October, November). The magenta polygon represents the Amazon River plume.

Fig. 3 shows the comparison of SST between the ROMS model and SODA dataset. SST presents higher temperatures than the SODA dataset in the area of the NBC retroflection, mainly during SON to DJF and in the NECC area. The cause of this large seasonal variation is probably a dynamic adjustment due to changes in the wind forcing over the tropical Atlantic and both local and remote wind stress that may play an important role in the SST variability (Bourles et al., 1999; Johns et al., 1998; Sharma et al., 2009). Tab. 2 summarizes the main results of simulated SST and SODA dataset, evidencing greater difference in DJF $\left(1.27^{\circ} \mathrm{C}\right)$, when the plume feeds the NECC. The ROMS model is well balanced in JJA. 


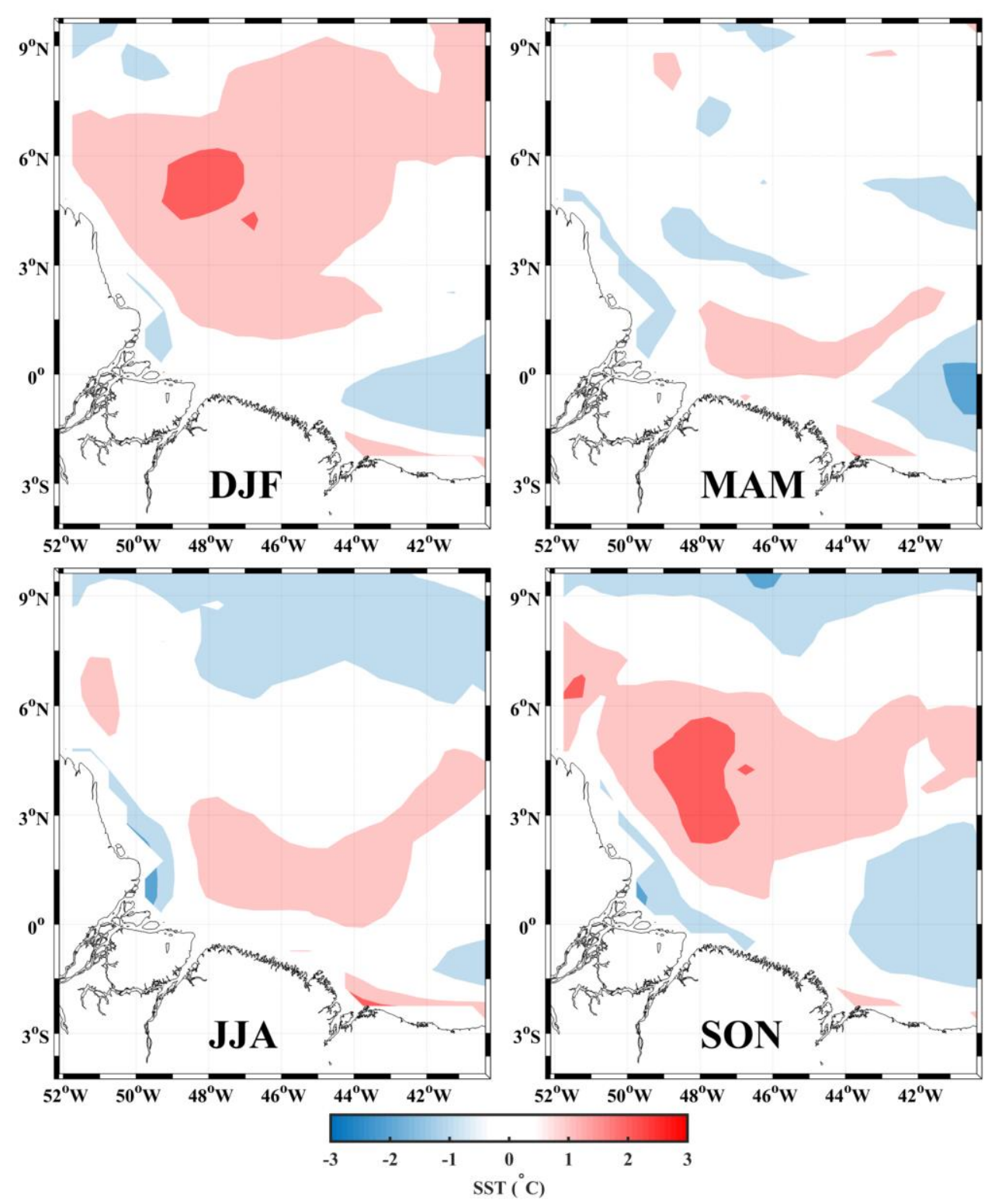

Figure 3. Mean seasonal cycle of the difference between the SST $\left({ }^{\circ} \mathrm{C}\right)$ of the ROMS model and the SODA dataset During the boreal winter (DJF-December, January, February), spring (MAM-March, April, May), summer (JJA-June, July, August), and fall (SON-September, October, November).

Table 2. Seasonal comparison of salinity and temperature at surface between the ROMS model and SODA dataset in EPLUME area. Mean value \pm standard deviation.

\begin{tabular}{lcccc}
\hline & \multicolumn{2}{c}{ SSS } & \multicolumn{2}{c}{ SST } \\
\cline { 2 - 5 } & SODA (psu) & ROMS (psu) & SODA $\left({ }^{\circ} \mathbf{C}\right)$ & ROMS $\left({ }^{\circ} \mathbf{C}\right)$ \\
\hline DJF & $35.97 \pm 0.02$ & $35.89 \pm 0.06$ & $27.43 \pm 0.05$ & $28.35 \pm 0.15$ \\
\hline MAM & $35.85 \pm 0.09$ & $36.02 \pm 0.03$ & $27.41 \pm 0.07$ & $27.72 \pm 0.14$ \\
\hline JJA & $35.32 \pm 0.09$ & $35.66 \pm 0.11$ & $27.95 \pm 0.02$ & $28.43 \pm 0.09$ \\
\hline SON & $35.54 \pm 0.06$ & $35.41 \pm 0.10$ & $28.01 \pm 0.03$ & $28.99 \pm 0.09$ \\
\hline
\end{tabular}


The difference of sea surface salinities between the ROMS model and SODA dataset is shown in Fig. 4. Mean simulated SSS presents lower salinities than SODA dataset in the area of the NBC retroflection mainly during MAM. In the months of SON, lower values of SSS follow the NECC.

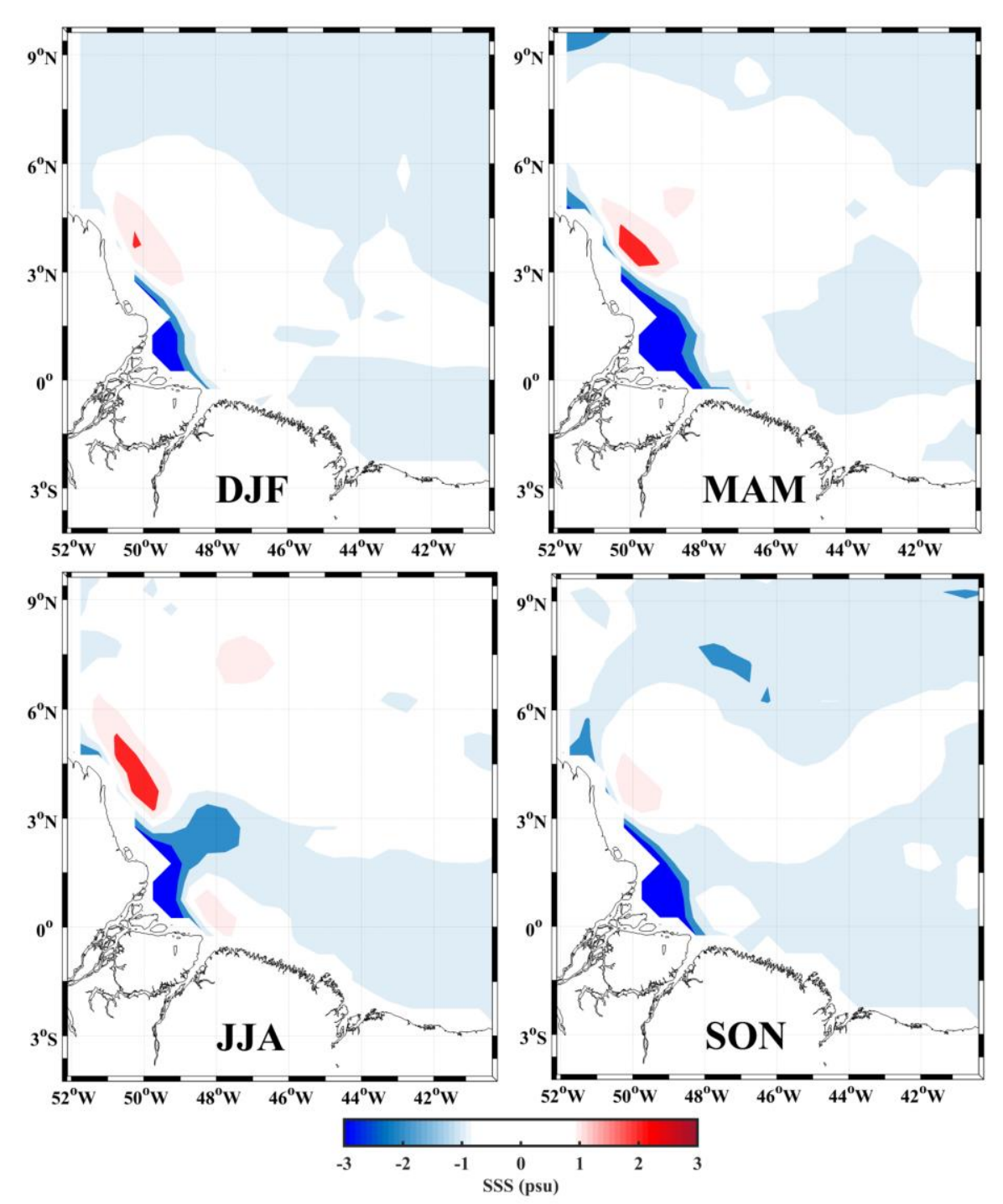

Figure 4. Mean seasonal cycle of the difference between the SSS (psu) of the ROMS model and the SODA dataset During the boreal winter (DJF-December, January, February), spring (MAM-March, April, May), summer (JJA-June, July, August), and fall (SON-September, October, November).

Tab. 2 above also shows a summary of the mean seasonal salinity cycles for the EPLUME area. The maximum difference observed was in JJA ( $0.34 \mathrm{psu})$ and the minimum difference was in DJF (0.08 psu). The ROMS model overestimate the SST, the with DJF period being the worstagreement and the MAM, the best one.

Fig. 5(a) shows the vertical profiles of the temperature at point P1 of the SODA dataset and the ROMS model in the DJF and JJA periods. The vertical profiles of the temperature are 
better adjusted below $300 \mathrm{~m}$ depth in both periods. In depths above $300 \mathrm{~m}$ the ROMS model overestimates the temperature and the main differences range between 0.7 to $1.7^{\circ} \mathrm{C}$. In JJA period there is a maximum difference of $0.04 \mathrm{~ms}^{-1}$ below $300 \mathrm{~m}$ and above this depth, the average difference was $0.17 \mathrm{~ms}^{-1}$ with a maximum difference of $0.21 \mathrm{~ms}^{-1}$ from 150 to $180 \mathrm{~m}$ depth (Fig. 5(b)). The profile of the current speed is well adjusted below the $300 \mathrm{~m}$ depth in the DJF period. The maximum difference in the DJF period was $0.18 \mathrm{~ms}^{-1}$ on the surface.
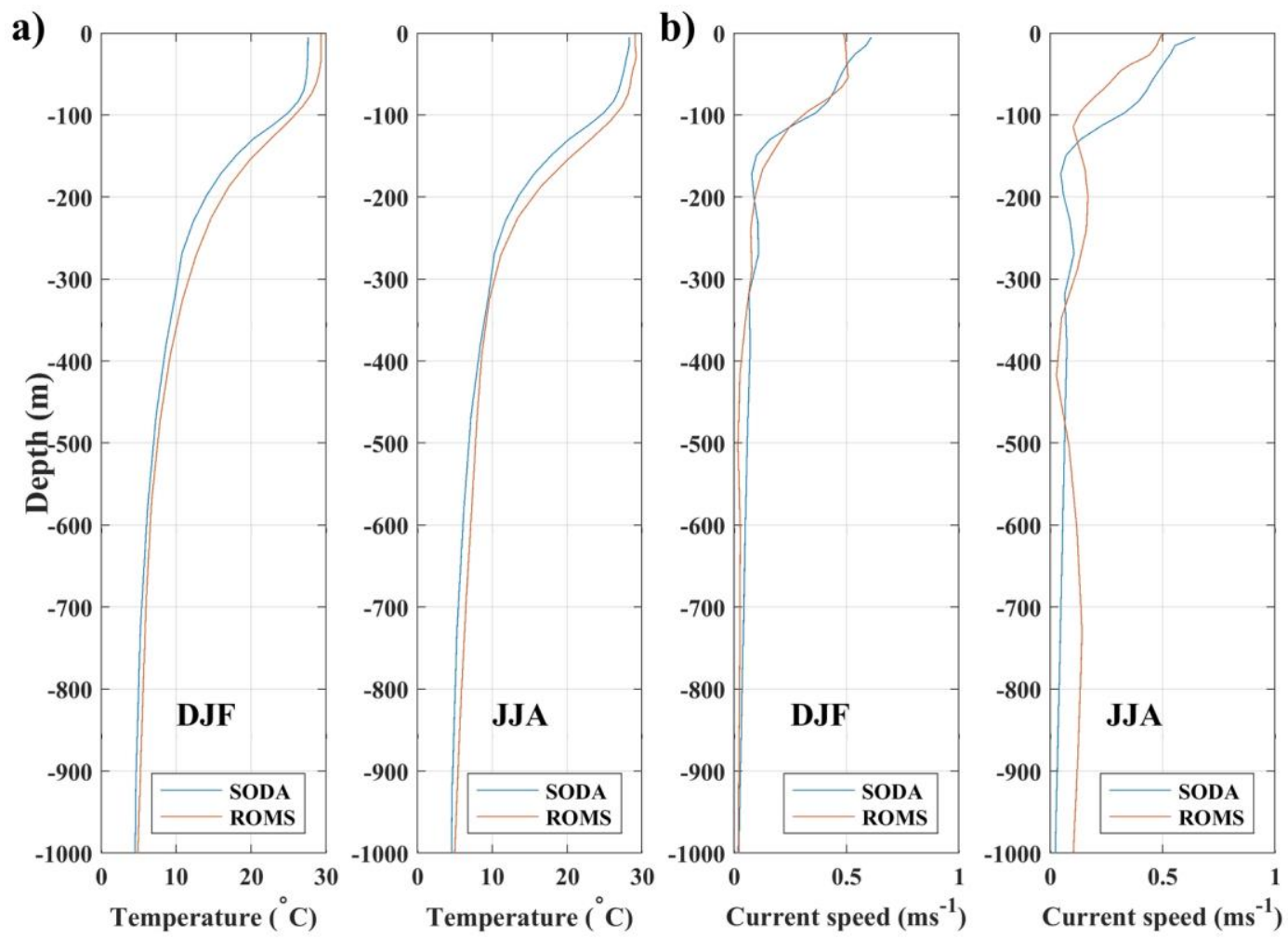

Figure 5. (a) Temperature and (b) current speed vertical profiles in DJF (December-January-February) and JJA (June-July-August) periods for SODA and ROMS at point P1.

In the north coast of Brazil, the continental shelf extends from 2 to $3^{\circ}$ from the coast, followed by the continental slope with an approximate width of $1^{\circ}$ varying the depths from 500 to $1900 \mathrm{~m}$ depth. The numerical simulation of oil/gas blowouts were located at 3 points of this continental slope.

Fig. 6(a) shows the mean seasonal velocity of the marine current, averaged between the surface and $100 \mathrm{~m}$ depth. The most intense currents form a band approximately wide and confined to the coastline, corresponds to the NBC. This current is more intense in the winter especially over the northwest part of the coast where it turns toward the east (in correspondence with the NBC retroflection), reaching speeds higher than $0.9 \mathrm{~ms}^{-1}$. In the spring, we found the less intense currents of the whole year with maximum values eastward of the Amazon River mouth, reaching up to $0.7 \mathrm{~ms}^{-1}$. In the summer, the currents in the NBC 
intensify vary from $0.5 \mathrm{~ms}^{-1}$ to speeds higher than $0.9 \mathrm{~ms}^{-1}$. In the autumn, as in the winter, the turn of the current to the east appears, better defining the NBC retroflection. Higher speeds are found along the coast more to the northwest and in the NBC retroflection, oscillating the current speed from $0.5 \mathrm{~ms}^{-1}$ to speeds higher than $0.9 \mathrm{~ms}^{-1}$.

(a)

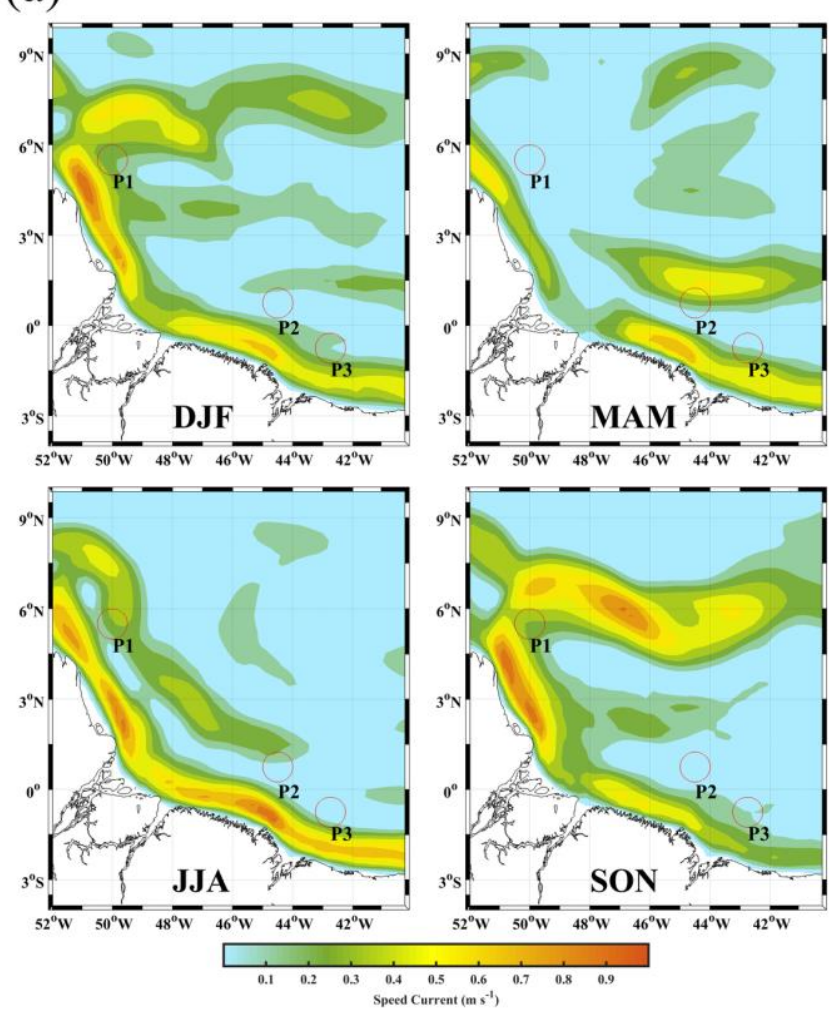

(b)
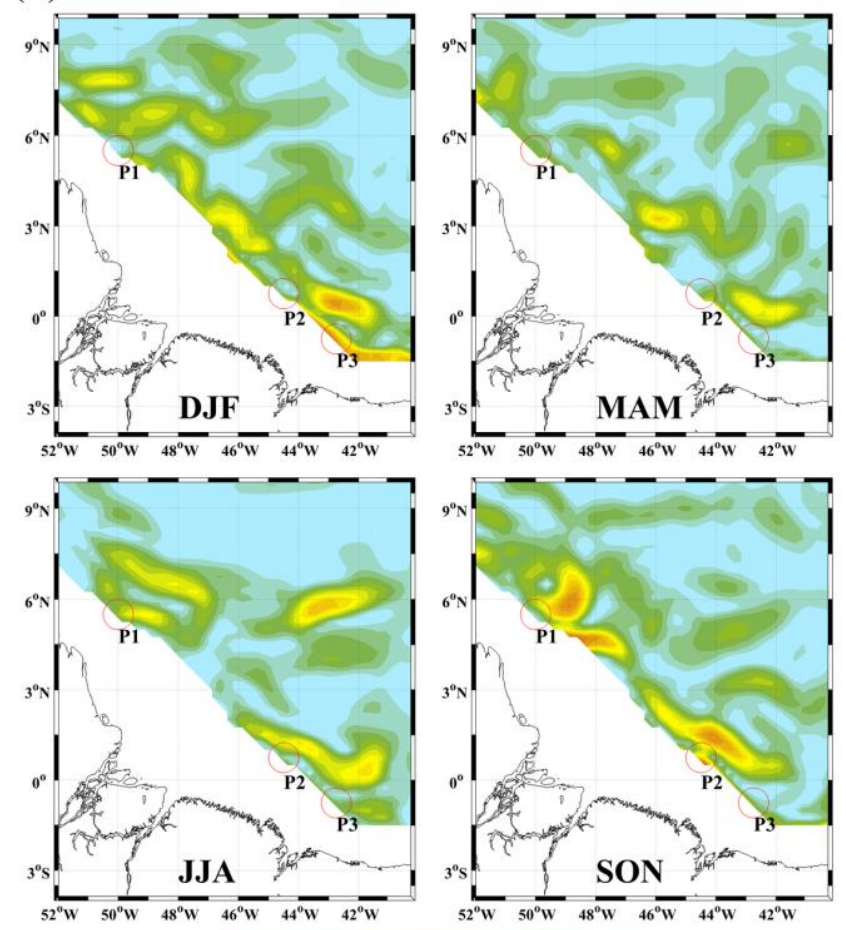

Figure 6. ROMS output of mean seasonal cycle of the currents measured (a) between the surface and 100 $\mathrm{m}$ depth (b) between 1000 and $1200 \mathrm{~m}$ depth during the winter (DJF-December, January, February), spring (MAM-March, April, May), summer (JJA-June, July, August), and fall (SON-September, October, November). The centers of the red circle represent the positions of the simulation points P1, P2 and P3.

The center of the red circles represents the positions of the P1, P2 and P3 simulation points. In winter the average speed is $0.25 \mathrm{~ms}^{-1}$, at P1, extremely low $\left(0.01 \mathrm{~ms}^{-1}\right)$ at P2 and it reaches $0.15 \mathrm{~ms}^{-1}$ at P3. In the spring, we find the lowest speeds of the year at P1, P2 and P3, oscillating between 0.01 and $0.25 \mathrm{~ms}^{-1}$. In the summer and in the autumn at P2 and P3, current speeds reach the minimum value $\left(0.01-0.15 \mathrm{~ms}^{-1}\right)$, increasing at $\mathrm{P} 1$ with respect to spring.

Fig. 6(b) shows the mean seasonal behavior of marine currents between 1000 and 1200 $\mathrm{m}$ depth. In general, at these depths the currents are very low, oscillating their speed between 0.01 and $0.15 \mathrm{~ms}^{-1}$. These currents are slightly less intense in the spring and a little more intense in the fall, mainly above $4^{\circ} \mathrm{N}$ and between 47 and $50^{\circ} \mathrm{W}$; and between $0.5-2^{\circ} \mathrm{N}$ and $42-$ $45^{\circ} \mathrm{W}$, reaching $0.15 \mathrm{~ms}^{-1}$, moving this last pattern towards the southeast in the winter. 
In the winter we find speeds of $0.15 \mathrm{~ms}-1$ at $\mathrm{P} 3$ and between $0.01-0.03 \mathrm{~ms}^{-1}$ at $\mathrm{P} 1$ and P2. The least intense currents are in the spring at all 3 points $\left(0.03-0.04 \mathrm{~ms}^{-1}\right)$. Similar speeds are found at P2 and P3 in the summer, increasing slightly at P1 to $0.06 \mathrm{~ms}^{-1}$. In the autumn, speeds at P3 do not differ from the summer, being somewhat lower at P1 and reaching up to $0.15 \mathrm{~ms}^{-1}$ at $\mathrm{P} 2$.

\section{OIL AND GAS PLUMES EVOLUTION}

Fig. 7 shows the monthly evolution of oil/gas plumes at P1. During the entire evaluated period, the plumes were type 3, with exception to September, where they reached the maximum diameter below $1000 \mathrm{~m}$ depth. Above this level, the diameter of the plumes began to decrease gradually until reaches the surface, oscillating between 54-76.5 m. The plumes reached the largest diameter in August, November and December and the lowest diameter was observed between May-July (Tab. 3).

Table 3. Monthly diameter and displacement of oil/gas plumes at points P1, P2 and P3.

\begin{tabular}{|c|c|c|c|c|c|c|c|c|c|}
\hline & \multicolumn{3}{|c|}{$\mathrm{P} 1$} & \multicolumn{3}{|c|}{ P2 } & \multicolumn{3}{|c|}{ P3 } \\
\hline & $\begin{array}{c}\text { Mean } \\
\text { diameter } \\
(\mathrm{m})\end{array}$ & $\begin{array}{l}\text { Displacement } \\
(\mathrm{m})\end{array}$ & $\begin{array}{c}\text { Evolution } \\
\text { Time } \\
\text { (hours) }\end{array}$ & $\begin{array}{c}\text { Mean } \\
\text { Diameter } \\
(\mathrm{m})\end{array}$ & $\begin{array}{c}\text { Displacement } \\
(\mathrm{m})\end{array}$ & $\begin{array}{c}\text { Evolution } \\
\text { Time } \\
\text { (hours) }\end{array}$ & $\begin{array}{c}\text { Mean } \\
\text { Diameter } \\
(\mathrm{m})\end{array}$ & $\begin{array}{c}\text { Displacement } \\
(\mathrm{m})\end{array}$ & $\begin{array}{c}\text { Evolution } \\
\text { Time } \\
\text { (hours) }\end{array}$ \\
\hline Jan & 56.4 & $(0.71,-0.70)$ & 8.04 & 75.5 & $(-0.30,0.20)$ & 7.26 & 58.9 & $(0.37,-0.32)$ & 6.30 \\
\hline Feb & 65.3 & $(0.50,-0.45)$ & 7.97 & 60.1 & $(-0.35,0.26)$ & 7.25 & 58.7 & $(-0.13,0.22)$ & 6.30 \\
\hline Mar & 62.1 & $(0.71,-0.71)$ & 8.06 & 54.1 & $(-0.33,0.24)$ & 7.25 & 58.7 & $(-0.09,0.23)$ & 6.30 \\
\hline Apr & 63.3 & $(0.36,-0.36)$ & 7.96 & 58.4 & $(0.14,-0.15)$ & 7.26 & 58.7 & $(-0.19,0.26)$ & 6.30 \\
\hline $\mathrm{Ma}$ & 54.5 & $(0.69,-073)$ & 8.05 & 60.7 & $(-0.10,0.15)$ & 7.25 & 58.8 & $(0.20,-0.18)$ & 6.30 \\
\hline$y$ & & & & & & & & & \\
\hline Jun & 54.0 & $(0.30,-0.28)$ & 7.95 & 55.3 & $(-0.52,0.34)$ & 7.26 & 58.8 & $(0.18,0.24)$ & 6.30 \\
\hline Jul. & 54.3 & $(0.38,0.41)$ & 7.96 & 73.1 & $(-0.54,0.32)$ & 7.27 & 58.8 & $(0.10,-0.03)$ & 6.30 \\
\hline Aug & 74.1 & $(-0.24,0.22)$ & 7.96 & 61.0 & $(-0.56,0.30)$ & 7.26 & 58.8 & $(-0.44,0.64)$ & 6.33 \\
\hline Sep & 60.3 & $\begin{array}{c}(-0.02,- \\
0.01)\end{array}$ & 7.96 & 56.5 & $(-0.47,0.25)$ & 7.26 & 58.7 & $(-0.28,0.36)$ & 6.30 \\
\hline Oct & 61.4 & $(0.35,-0.33)$ & 7.97 & 79.5 & $(-0.44,0.26)$ & 7.25 & 58.7 & $(-0.39,0.47)$ & 6.31 \\
\hline Nov & 70.6 & $(0.36,-0.24)$ & 7.97 & 54.5 & $(-0.42,0.19)$ & 7.25 & 58.7 & $(-0.19,0.32)$ & 6.30 \\
\hline Dec & 76.5 & $(0.54,-0.69)$ & 8.02 & 79.7 & $(-0.26,0.16)$ & 7.26 & 58.7 & $(-0.37,0.55)$ & 6.32 \\
\hline
\end{tabular}



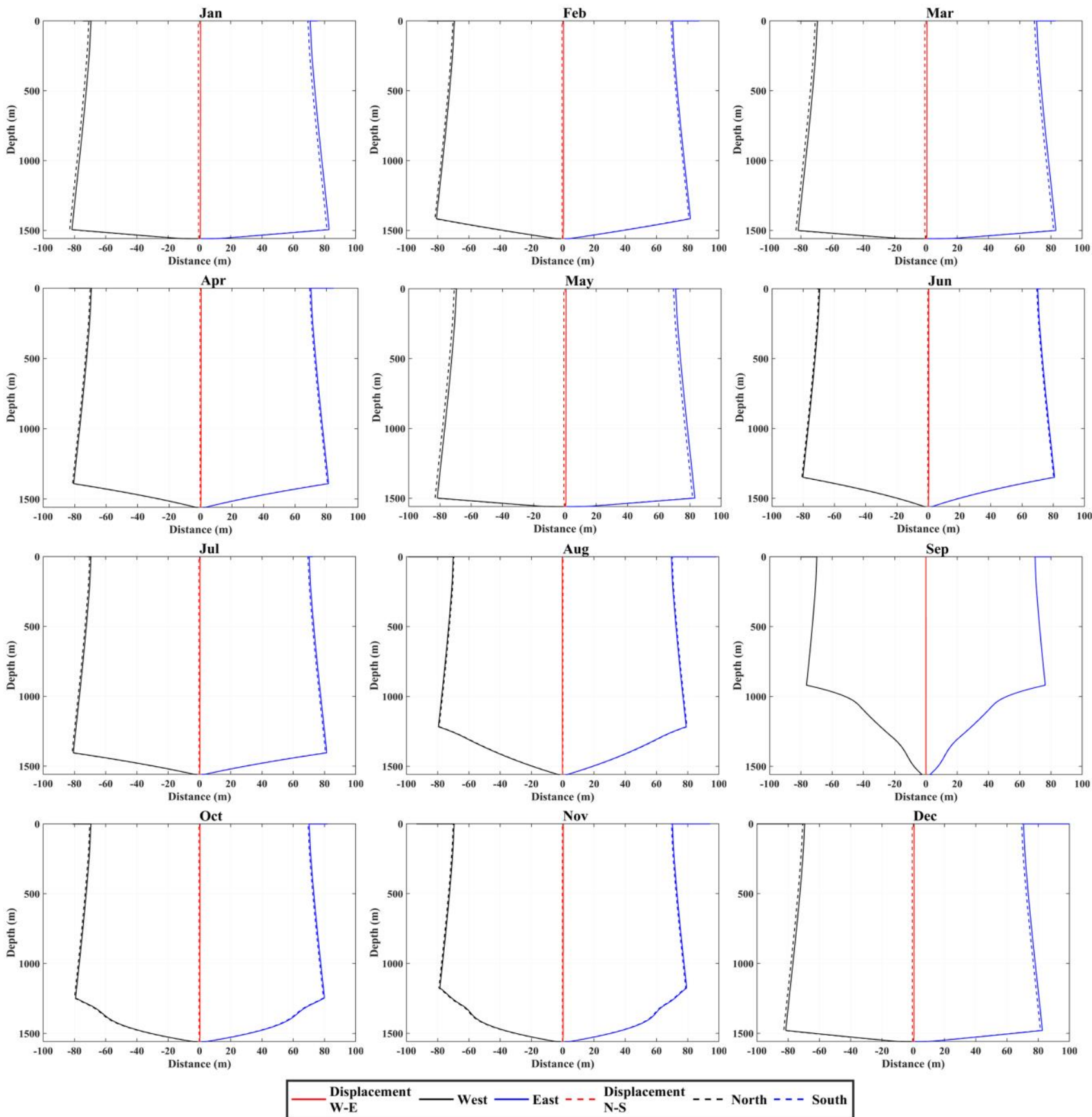

Figure 7. Monthly oil/gas plume evolution at P1. The solid lines represent the west $(-)$ and east $(+)$ directions. The dashed lines represent the north $(-)$ and south $(+)$ directions. The red color is the displacement of the plumes from the bottom. The black color represents the radius to the west and north. The blue color represents the radius to the east and south.

The largest displacements of the plume from the blowout point were approximately $1 \mathrm{~m}$ in January and May. The mean arrival time of the oil/gas plumes to the surface was 7.99 hours and difference between the months was minimal.

Fig. 8 shows the monthly evolution of the oil/gas plumes at P2. As already verified in P1, all the plumes are were of type 3 . All the plumes reach their maximum diameter below $1000 \mathrm{~m}$, 
decreasing their diameter until they reach the surface (54.1-79.7 $\mathrm{m})$. The largest diameters in the surface corresponded to the months of January, October and December. The largest displacements of P2 plume occurred from June to August and were approximately $0.64 \mathrm{~m}$ (Tab. 3). The average time of arrival at the surface was 7.26 hours.
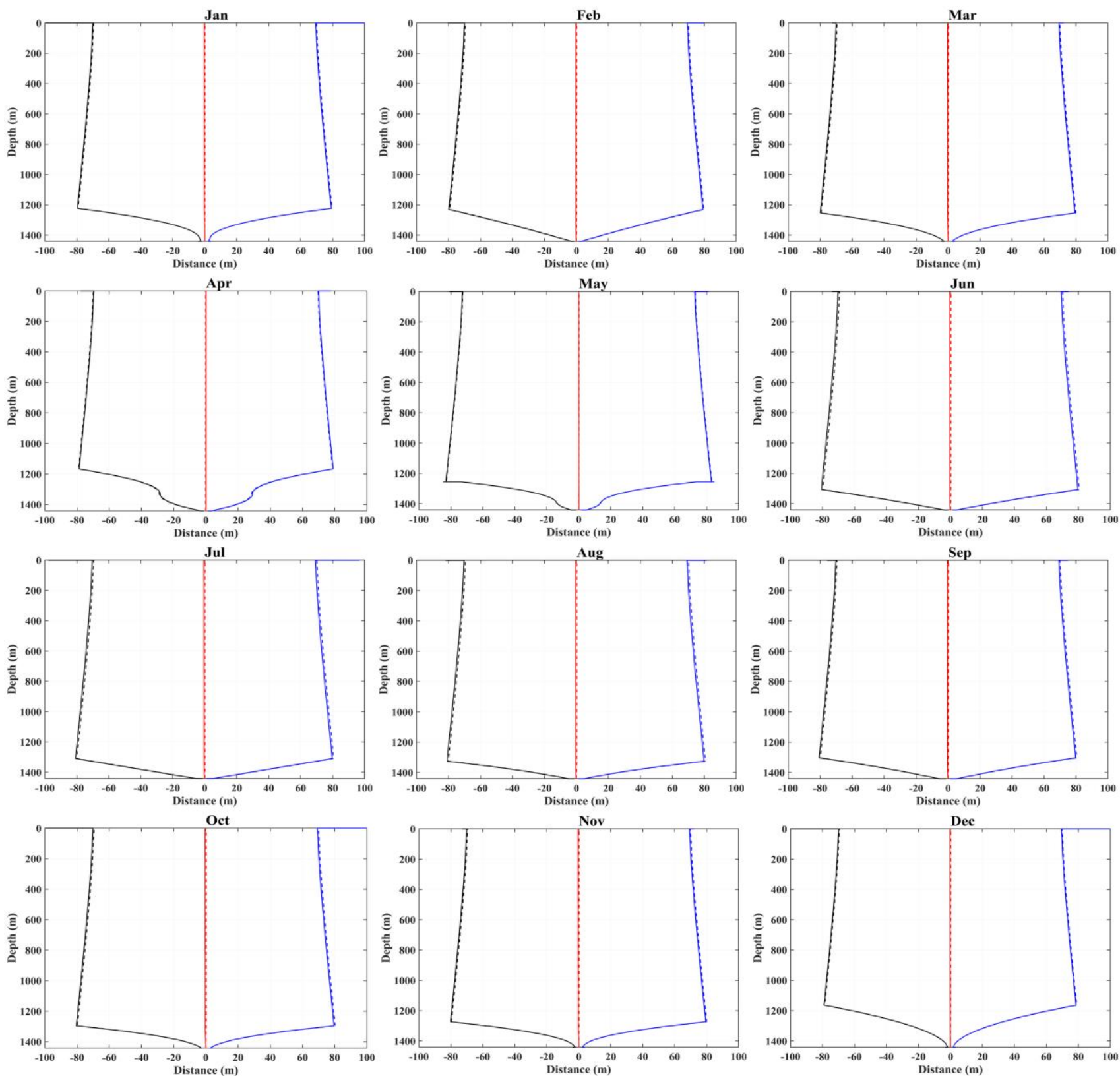

$$
{ }_{\text {W-E }}^{\text {Displacement }} \text { West — East - - - Displacement }- \text { N-S - North - - - South }
$$

Figure 8. Monthly oil/gas plume evolution at P2. The solid lines represent the west $(-)$ and east $(+)$ directions. The dashed lines represent the north $(-)$ and south $(+)$ directions. The red color is the displacement of the plumes from the bottom. The black color represents the radius to the west and north. The blue color represents the radius to the east and south. 
The pattern of oil/gas plume evolution already observed at the points P1 and P2 (type 3) was also verified at P3 (Fig. 9). The plumes at P3 reaching its largest diameter below $1000 \mathrm{~m}$ depth except for the months of May and July, where the diameter at the surface was almost invariant during all months (58.7-58.9 m). As shown in Tab. 3, the displacement of the plumes from its point of origin occurred in August and was $0.78 \mathrm{~m}$. The plumes evolution time was practically the same, oscillating between 6.30 and 6.33 hours.
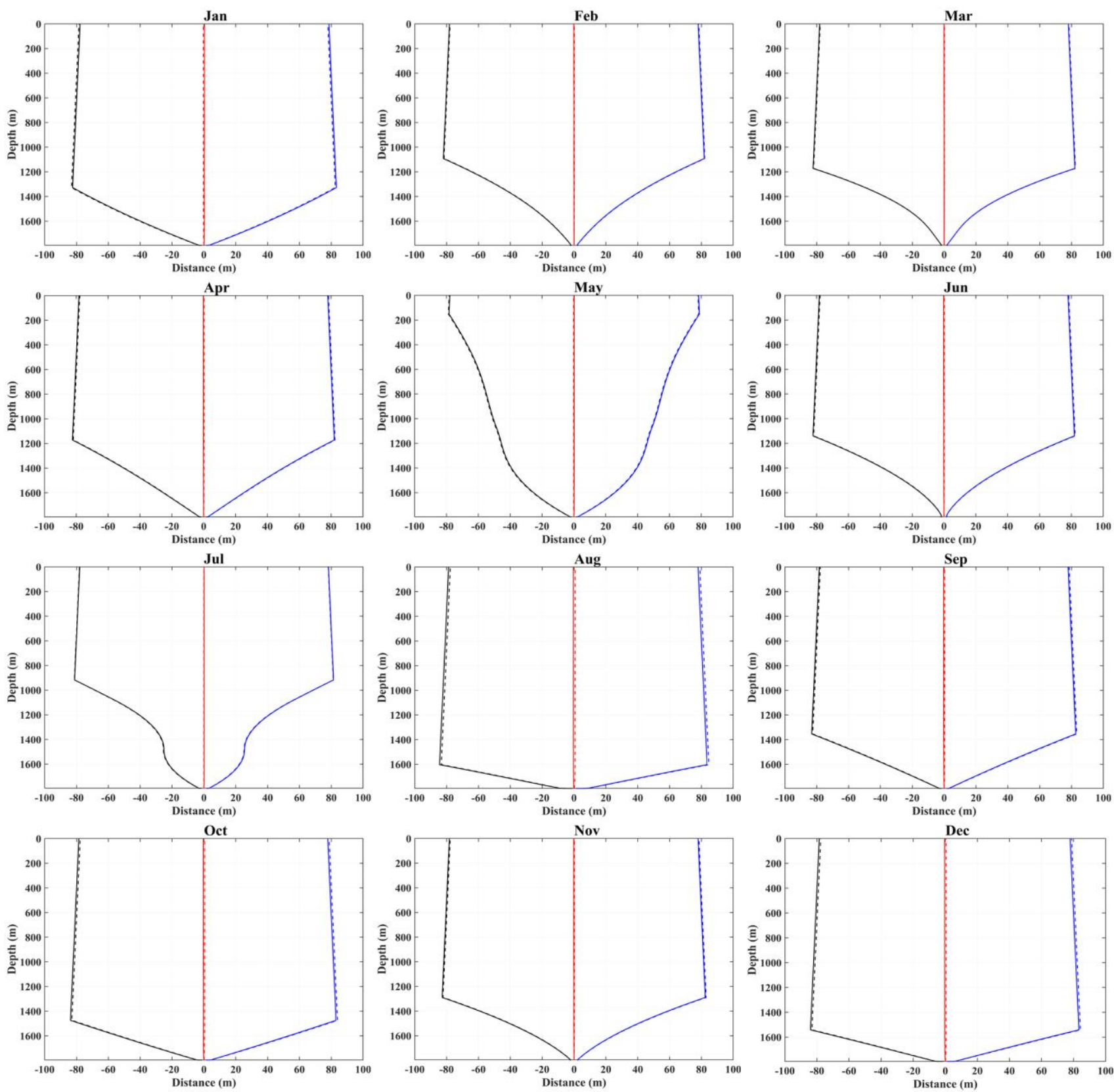

Displacement
W-E

Figure 9. Monthly oil/gas plume evolution at P3. The solid lines represent the west $(-)$ and east $(+)$ directions. The dashed lines represent the north $(-)$ and south $(+)$ directions. The red color is the displacement of the plumes from the bottom. The black color represents the radius to the west and north. The blue color represents the radius to the east and south. 
Fig. 10(a) shows the vertical profiles of the current velocity for March at point P1 and for November at point P3. In both profiles, the plume simulations show that the maximum diameters of these were reached below 1000 m depth (Fig. 7 and Fig. 9). The bottom speed of points $\mathrm{P} 1$ and $\mathrm{P} 3$ is greater than $0.1 \mathrm{~ms}-1$ and less than $0.2 \mathrm{~ms}-1$, thus maintaining the entire water column up to $200 \mathrm{~m}$ depth. This behavior is very similar to the rest of the profiles at all points, with the exception of September, at point P1, and of May and July, at point P3.

(a)

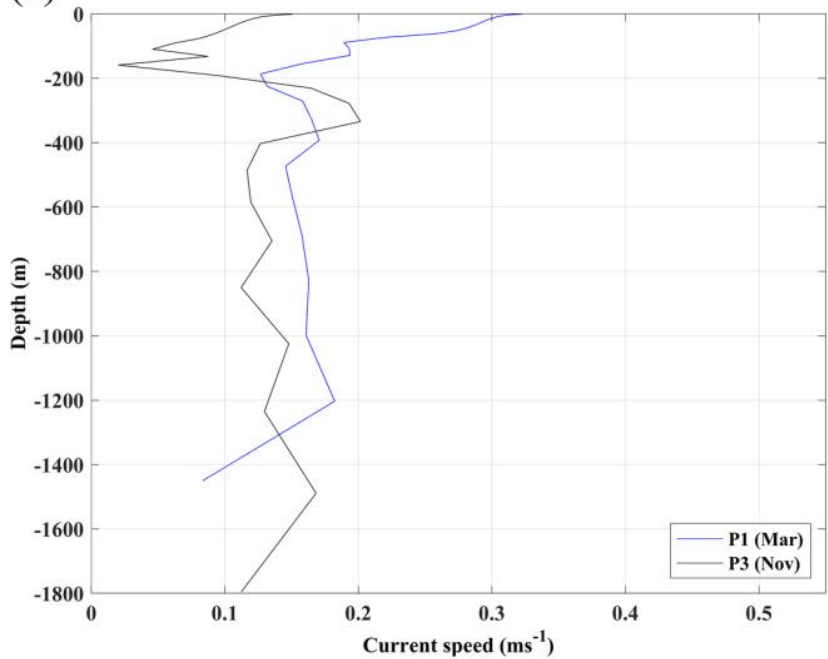

(b)

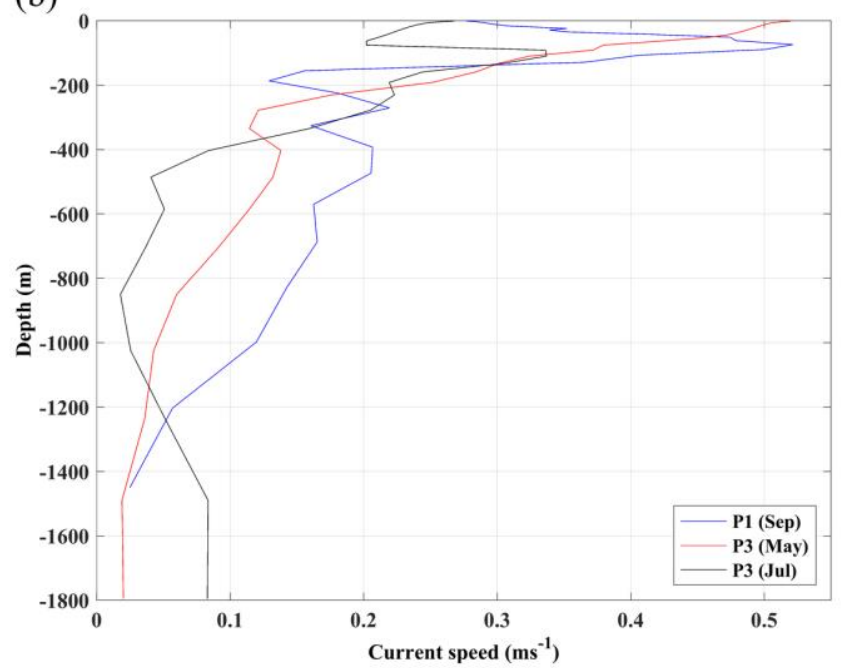

Figure 10. Vertical profiles of the current speed (a) at P1 (March) and P3 (November) and (b) at P1 (September) and P3 (May and July).

In September, at P1 (Fig. 10(b)), the current speed at the bottom was almost zero (approximately $0.02 \mathrm{~ms}-1$ ). From the bottom, the velocity grew very slowly as the depth decreased to $1000 \mathrm{~m}(0.12 \mathrm{~ms}-1)$. The speed began to increase a little faster from $1000 \mathrm{~m}$ depth to the surface, which means that the maximum diameter was reached between 900 and $1000 \mathrm{~m}$ depth. In May at P3 (Fig. 10(b)) the behavior of the plume in the bottom was also almost zero, but the increase in speed began near the $1500 \mathrm{~m}$ depth, which was much slower than in the previous case. Up to almost $200 \mathrm{~m}$ depth the speed did not exceed $0.2 \mathrm{~ms}-1$ and, above that, where the plume reached its maximum diameter, it began to grow sharply until exceeding 0.5 ms-1 on the surface. At this same point, in July (Fig. 10(b)), the current speed was less than $0.1 \mathrm{~ms}-1$ and maintained that value up to $1500 \mathrm{~m}$ depth. It began to decrease to approximately $850 \mathrm{~m}$ depth and then, it increased from above this depth, reaching its maximum diameter. 
Using the coefficient 0.2 in the Eq. 1 did not get good results because the bottom current speed at the three points was very small, $\left|V_{-} 0\right| \rightarrow 0$, which this implied that $\Delta t \rightarrow \infty$. Thus it was necessary to adjust the coefficient to estimate $\Delta$ t. The Eq. 2 below was then considered.

$$
\Delta \mathrm{t}= \begin{cases}0.025 \frac{b_{0}}{\left|V_{0}\right|} & \text { for } \mathrm{P} 1 \text { and } \mathrm{P} 2 \\ 0.0375 \frac{b_{0}}{\left|V_{0}\right|} & \text { for } \mathrm{P} 3\end{cases}
$$

\section{CONCLUSION}

This study characterizes the behavior of the plumes produced by the oil/gas blowouts in deep waters located at the continental slope in the northwest coast of Brazil, combining the ROMS and the GAS_DOCEAN models. The salinity and temperature of the hydrodynamic model were well adjusted to the SODA dataset, both on the surface and in the vertical profiles. All oil/gas plumes were type 3 and the oceanographic characteristics in the 3 points of the numerical simulations similar.

At P1, the mean diameter at the surface varied between $54-76.5 \mathrm{~m}$ and, at the bottom, the plume displacement from its origin was approximately $1 \mathrm{~m}$. The average time it took to reach the surface was 7.99 hours; however, it was slower than in p2 (7.26 hours). The largest distance of displacement from P2 point of origin was $0.64 \mathrm{~m}$ and its average diameter on the surface ranged 54.1-79.7 m.

At P3, the displacement of the plume from its origin was $0.78 \mathrm{~m}$. The mean diameter on the surface at this point varied between 58.7 and $58.9 \mathrm{~m}$. The plume evolution time to the surface remained almost invariant (6.30-6.33 hours). The small plume displacement from its origin is was due to the low speeds in the vertical profile.

To obtain good results in the numerical simulations of the plumes, it was necessary to adjust the coefficient for $\Delta t$ computation. The equation suggested by Lee and Cheung (1990) was modified to $\Delta \mathrm{t}=0.025 \mathrm{~b}_{0} /\left|\mathrm{V}_{0}\right|$ for $\mathrm{P} 1$ and $\mathrm{P} 2$; and $\Delta \mathrm{t}=0.0375 \mathrm{~b}_{0} /\left|\mathrm{V}_{0}\right|$ for $\mathrm{P} 3$.

\section{ACKNOWLEDGEMENTS}

The first author thanks to Human Resources Program (PRH-47) of the Agência Nacional do Petróleo (ANP) for the concession of PhD scholarships. This work is also part of the Project Pólo de Interação para o Desenvolvimento de Estudos conjuntos em Oceanografia do Atlântico Tropical (PILOTE) and is a contribution of the Project Simulating the Amazon River Plume and its Impacts using Climate Models (CAPES-TAMU, Grant 99999.003440/2015-00). 


\section{REFERENCES}

Abimbola, M., Khan, F. and Khakzad, N. (2014), Dynamic safety risk analysis of offshore drilling, Journal of Loss Prevention in the Process Industries, Vol. 30, pp. 74-85.

de Andrade, M.M.N., Szlafsztein, C.F., Souza-Filho, P.W.M., dos Reis A.A. and Gomes, M.K.T. (2010), Journal of Environmental Management, Vol. 91, n. 10, pp. 1972-1980

Agência Nacional do Petróleo, Gás Natural e Biocombustíveis (ANP) (2017), Dados Georreferenciados dos Blocos em Exploração e Campos de Produção (Georeferenced Data of Blocks in Exploration and Production Fields), em: http://www.brasil-

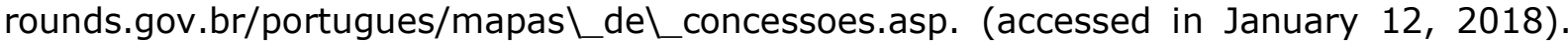
Only in Portuguese.

Antonov, J., Seidov, D., Boyer, T., Locarnini, R., Mishonov, A., Garcia, H., Baranova, O., Zweng, M. and Johnson, D. (2010), Salinity, in Levitus, S. (Ed.), World Ocean Atlas 2009, US Gov. Print. Off., Washington, DC, vol. 2.

Arnault, S., Bourles, B., Gouriou, Y. and Chuchla, R. (1999), Intercomparison of upper layer circulation of the western equatorial Atlantic Ocean: In situ and satellite data, Journal of Geophysical Research, Vol. 104, pp. 21171-21194.

Bourles, B., Gouriou, Y. and Chuchla, R. (1999), On the circulation in the upper layer of the western Equatorial Atlantic, Journal of Geophysical Research, Vol. 104, pp. 21151-21170.

Carton, J.A., Chepurin, G. and Cao, X. (2000), A Simple Ocean Data Assimilation Analysis of the Global Upper Ocean 1950-95. Part I: Methodology, Journal of Physical Oceanography, Vol. 30, pp. 294-309.

Carvalho, M. and Gherardi, D.F.M. (2003), Uso de transformação IHS e classificação não supervisionada por regiões para o mapeamento da sensibilidade ambiental ao derramamento de óleo, in XI Simpósio Brasileiro de Sensoriamento Remoto, Belo Horizonte (MG). Anais... Belo Horizonte, pp. 1515-1523.

Charrouf, Z. and Guillaume, D. (2008), Argan oil: Occurrence, composition and impact on human health, European Journal of Lipid Science and Technology, Vol. 110, n. 7, pp. 632636.

Chen, F. and Yapa, P.D. (2001), Estimating hydrate formation and decomposition of gases released in a deep-water ocean plume, Journal of Marine Systems, Vol. 30, pp. 21-32.

Chen, F. and Yapa, P.D., (2004), Modeling gas separation from a bent deep-water oil and gas jet/plum, Journal of Marine Systems, Vol. 45, pp. 189-203. 
Coles, V.J., Brooks, M.T., Hopkins, J., Stukel, M.R., Yager, P.L. and Hood, R.R. (2013), The pathways and properties of the Amazon river plume in the tropical North Atlantic Ocean, Journal of Geophysical Research: Oceans, Vol. 118, pp. 6894-6913.

Da Silva, A., Young, A.C. and Levitus, S. (1994), Atlas of surface marine data 1994, volume 1: Algorithms and procedures, Technical Report 6.

Dai, A. and Trenberth, K.E., (2002), Estimates of Freshwater Discharge from Continents: Latitudinal and Seasonal Variations, Journal of Hydrometeorology, Vol. 3, pp. 660-687.

Dasanayaka, L.K. and Yapa, P.D. (2009), Role of plume dynamics phase in a deep-water oil and gas release model, Journal of Hydro-environment Research, Vol. 2, pp. 243-253.

De Dominicis, M., Pinardi, N., Zodiatis, G. and Lardner, R., (2013), MEDSLIK-II, a Lagrangian marine surface oil spill model for short-term forecasting-Part 1: Theory, Geoscientific Model Development, Vol. 6, pp. 1851-1869.

Dessier, A. and Donguy, J.R. (1994), The sea surface salinity in the tropical Atlantic between 10 S and $30 \mathrm{~N}$-seasonal and interannual variations (1977-1989), Deep Sea Research Part I: Oceanographic Research Papers, Vol. 41, pp. 81-100.

D'Onofrio, E., Oreiro, F. and Fiore, M. (2012), Simplified empirical astronomical tide model-An application for the Río de la Plata estuary, Computers \& Geosciences, Vol. 44, pp. 196202.

Egbert, G.D., Bennett, A.F. and Foreman, M.G.G. (1994), TOPEX/POSEIDON tides estimated using a global inverse model, Journal of Geophysical Research: Oceans, Vol. 99, pp. 24821-24852.

Egbert, G.D. and Erofeeva, S.Y., (2002), Efficient inverse modeling of barotropic ocean tides, Journal of Oceanic and Atmospheric Technology, Vol. 19, pp. 183-204.

E\&P Forum/UNEP - United Nations Environment Programme (1997), Environment management in oil and gas exploration and production: An overview of issues and management approach, Technical Report 37.

Fannelop, T. and Sjoen, K. (1980), Hydrodynamics of underwater blowouts, in: 18th Aerospace Sciences Meeting, 219p.

Foltz, G.R., Schmid, C. and Lumpkin, R. (2015), Transport of Surface Freshwater from the Equatorial to the Subtropical North Atlantic Ocean, Journal of Physical Oceanography, Vol. 45, pp. $1086-1102$.

Fratantoni, D. (2001), North Atlantic surface circulation during the 1990's North Atlantic surface circulation during observed with satellite-tracked drifters, Journal of Geophysical Research: Oceans, Vol. 106, pp. 22067-22093. 
Fratantoni, D.M., Johns, W.E. and Townsend, T.L. (1995), Rings of the North Brazil Current: Their structure and behavior inferred from observations and a numerical simulation, Journal of Geophysical Research, Vol. 100, pp. 10633-10654.

Friedl, M.J. and Fanneløp, T. (2000), Bubble plumes and their interaction with the water surface, Applied Ocean Research, Vol. 22, pp. 119-128.

Garza-Gil, M.D., Prada-Blanco, A. and Vázquez-Rodríguez, M.X. (2006), Estimating the shortterm economic damages from the Prestige oil spill in the Galician fisheries and tourism, Ecological Economics, Vol. 59, n. 4, pp. 842-849.

Goes, M., Molinari, R., da Silveira, I. and Wainer, I. (2005), Retroflections of the north Brazil current during February 2002, Deep Sea Research Part I: Oceanographic Research Papers, Vol. 52, pp. 647-667.

Grodsky, S.A. and Carton, J.A. (2002), Surface drifter pathways originating in the equatorial Atlantic cold tongue, Geophysical Research Letters, Vol. 29, n. 23, pp. 62(1)- 62(4).

Gundlach, E.R. and Hayes, M.O. (1978), Vulnerability of coastal environments to oil spill impacts, Marine Technology Society Journal, Vol. 12, pp. 18-27.

Haidvogel, D., Arango, H., Hedstrom, K., Beckmann, A., Malanotte-Rizzoli, P. and Shchepetkin, A. (2000), Model evaluation experiments in the North Atlantic basin: Simulations in nonlinear terrain-following coordinates, Dynamics of Atmospheres and Oceans, Vol. 32, pp. 239-282.

International Energy Agency (IEA) (2009), World Energy Outlook, Paris, 698p.

International Energy Agency (IEA) (2011), World Energy Outlook, Paris, 666p.

International Tanker Owners Pollution Federation (ITOPF) (2016), Oil Tanker Spill Statistics, em: http://www.itopf.com/knowledge-resources/data-statistics/statistics/ (accessed in July 7,2017$)$.

Johansen, $\varnothing$. (2000), DeepBlow-a Lagrangian plume model for deep water blowouts, Spill Science \& Technology Bulletin, Vol. 6, pp. 103-111.

Johansen, $\varnothing$. (2003), Development and verification of deep-water blowout models, Marine Pollution Bulletin, Vol. 47, pp. 360-368.

Johns, W., Lee, T., Schott, F., Zantopp, R. and Evans, R. (1990), The North Brazil Current Retroflection: Seasonal Structure and Eddy Variability, Journal of Geophysical Research, Vol. 95, pp. 22103-22120.

Johns, W.E., Lee, T.N., Beardsley, R.C., Candela, J., Limeburner, R. and Castro, B. (1998), Annual cycle and variability of the North Brazil Current, Journal of Physical Oceanography, Vol. 28, pp. 103-128. 
Lara, I. (2014), Geopolítica y governance de los hidrocarburos, Relaciones Internacionales, Vol. 23, n. 46, pp 149-175.

Lee, J.H. and Cheung, V. (1990), Generalized Lagrangian model for buoyant jets in current, Journal of Environmental Engineering, Vol. 116, pp. 1085-1106.

Leite, F.S., Silva, M.A., Araujo, M., Silva, R.A. and Droguett, E.L. (2014), Modeling Subsurface Gas Release in Tropical and Shallow Waters: Comparison with Field Experiments off Brazil's Northeast Coast, Human and Ecological Risk Assessment: An International Journal, Vol. 20, 150-173.

Lentz, S.J. (1995), The Amazon River Plume during AMASSEDS: Subtidal current variability and the importance of wind forcing, Journal of Geophysical Research: Oceans, Vol. 100, pp. 2377-2390.

Locarnini, R., Mishonov, A., Antonov, J., Boyer, T., Garcia, H., Baranova, O., Zweng, M. and Johnson, D. (2010), Temperature, in Levitus, S. (Ed.), World Ocean Atlas 2009, US Gov. Print. Off., Washington, DC, vol. 1, 184 p.

Malanotte-Rizzoli, P., Hedstrom, K., Arango, H. and Haidvogel, D.B. (2000), Water mass pathways between the subtropical and tropical ocean in a climatological simulation of North Atlantic, Dynamics of Atmospheres and Oceans, Vol. 32, pp. 331-371.

Maximenko, N. and Hafner, J. (2010), SCUD: Surface Currents form Diagnostic model, Technical Report 5.

Mendelssohn, I.A., Andersen, G.L., Baltz, D.M., Caffey, R.H., Carman, K.R., Fleeger, J.W., Joye, S.B., Lin, Q., Maltby, E. and Overton, E.B. (2012), Oil impacts on coastal wetlands: implications for the Mississippi River Delta ecosystem after the Deepwater Horizon oil spill, BioScience, Vol. 62, n. 6, pp. 562-574.

Michel, J., Hayes, M.O. and Brown, P.J. (1978), Application of an oil spill vulnerability index to the shoreline of lower Cook Inlet, Alaska, Environmental Geology, Vol. 2, pp. 107-117.

Moon, J.H. and Song, Y.T. (2014), Seasonal salinity stratifications in the near-surface layer from Aquarius, Argo, and an ocean model: Focusing on the tropical Atlantic/Indian Oceans, Journal of Geophysical Research: Oceans, Vol. 119, pp. 6066-6077.

Moura, R.L., Amado-Filho, G.M., Moraes, F.C., Brasileiro, P.S., Salomon, P.S., Mahiques, M.M., Bastos, A.C., Almeida, M.G., Silva, J.M., Araujo, B.F., Brito, F.P., Rangel, T.P., Oliveira, B.C.V., Bahia, R.G., Paranhos, R.P., Dias, R.J.S., Siegle, E., Figueiredo Jr, A.G., Pereira, R.C., Leal, C.V., Hajdu, E., Asp, N.E., Gregoracci, G.B., Neumann-Leitão, S., Yager, P.L., Francini-Filho, R.B., Fróes, A., Campeão, M., Silva, B.S., Moreira, A.P.B., Oliveira, L., Soares, A.C., Araujo, L., Oliveira, N.L., Teixeira, J.B., Valle, R.A.B, Thompson, C.C., 
Rezende, C.E. and Thompson, F.L. (2016), An extensive reef system at the Amazon River mouth, Science Advances, Vol. 2, n. 4, pp. e1501252.

Muller-Krager, F.E., McClain, C.R. and Richardson, P.L. (1988), The dispersal of the Amazons water, Nature, Vol. 333, pp. 56-59.

Neff, J.M., Rabalais, N.N. and Boesch, D.F. (1987), Long-term environmental effects of offshore oil and gas development, in Boesch, D.F. Rabalais, N.N. (Eds.), Offshore oil and gas development activities potentially causing long-term environmental effects, pp. 149-173, London (UK), [Chapter 4].

North, E.W., Adams, E., Schlag, Z.Z., Sherwood, C.R., He, R.R., Hyun, K.H.K. and Socolofsky, S.A. (2011), Simulating oil droplet dispersal from the Deepwater Horizon spill with a Lagrangian approach, in Monitoring and Modeling the Deepwater Horizon Oil Spill: A Record-Breaking Enterprise, Geophysical Monograph Series, Vol. 195, pp. 217-226.

O'Rourke, D. and Connolly, S. (2003), Just oil? The distribution of environmental and social impacts of oil production and consumption, Annual Review of Environment and Resources, Vol. 28, n. 1, pp. 587-617.

Panzer, I., Lines, S., Mak, J., Choboter, P. and Lupo, C., (2013), High Performance Regional Ocean Modeling with GPU Acceleration, IEEE/MTS OCEANS.

Penven, P., Roy, C., Colin de Verrdière, A. and Largier, J. (2000), Simulation of a coastal jet retention process using a barotropic model, Oceanologica Acta, Vol. 23, pp. 615-634.

Peterson, R.G. and Stramma, L. (1991), Upper-level circulation in the South Atlantic Ocean, Progress in Oceanography, Vol. 26, pp. 1-73.

Prates, C.P.T., Pierobon, E.C., da Costa, R.C. and de Figueiredo, V.S. (2006), Evolução da oferta e da demanda de gás natural no Brasil, BNDES Setorial, Rio de Janeiro, n. 24, pp. 35-68.

Premathilake, L.T., Yapa, P.D., Nissanka, I.D. and Kumarage, P., (2016), Impact on water surface due to deepwater gas blowouts, Marine Pollution Bulletin, Vol. 112, pp. 365-374.

Reed, M., Johansen, Ø., Brandvik, P.J., Daling, P., Lewis, A., Fiocco, R., Mackay, D. and Prentki, R. (1999), Oil spill modeling towards the close of the 20th century: overview of the state of the art, Spill Science \& Technology Bulletin, Vol. 5, pp. 3-16.

Richardson, P.L. and Reverdin, G. (1987), Seasonal cycle of velocity in the Atlantic North Equatorial Countercurrent as measured by surface drifters, current meters, and ship drifts, Journal of Geophysical Research: Oceans, Vol. 92, pp. 3691-3708.

Richardson, P.L. and Walsh, D. (1986), Mapping climatological seasonal variations of surface currents in the tropical Atlantic using ship drifts, Journal of Geophysical Research, Vol. 91, pp. 10537-10550. 
Salisbury, J., Vandemark, D., Campbell, J., Hunt, C., Wisser, D., Reul, N. and Chapron, B. (2011), Spatial and temporal coherence between Amazon River discharge, salinity, and light absorption by colored organic carbon in western tropical Atlantic surface waters, Journal of Geophysical Research, Vol. 116, C0OH02, pp 1-14.

dos Santos, V.F., Mendes, A.C. and da Silveira, O.F.M. (2016), Atlas de sensibilidade ambiental ao óleo da Bacia Marítima da Foz do Amazonas, Macapá: IEPA.

Sharma, N., Anderson, S.P., Brickley, P., Nobre, C. and Cadwallader, M.L. (2009), Quantifying the Seasonal and Interannual Variability of the Formation and Migration Pattern of North Brazil Current Rings, IEEE. pp. 1-7. Conference paper: OCEANS 2009, MTS/IEEE Biloxi Marine Technology for Our Future: Global and Local Challenge.

Shchepetkin, A.F. and McWilliams, J.C. (2005), The regional oceanic modeling system (ROMS): a split-explicit, free-surface, topography-following-coordinates oceanic model, Ocean Modelling, Vol. 9, pp. 347-404.

Silva, M., Araujo, M., Servain, J., Penven, P. and Lentini, C.A.D. (2009), High-resolution regional ocean dynamics simulation in the southwestern tropical Atlantic, Ocean Modelling, Vol. 30, pp. 256-269.

da Silva Junior, O.M. and Magrini, A. (2014), Exploração de hidrocarbonetos na Foz do Rio Amazonas: perspectivas de impactos ambientais no âmbito das áreas ofertadas na 110 rodada de licitações da Agência Nacional do Petróleo, Revista GeoAmazônia, Vol. 2, pp. $159-172$.

da Silveira, I.C., Brown, W.S. and Flierl, G.R. (2000), Dynamics of the North Brazil Current retroflection region from the Western Tropical Atlantic Experiment observations, Journal of Geophysical Research: Oceans, Vol. 105, pp. 28559-28583.

Skogdalen, J.E., Utne, I.B. and Vinnem, J.E. (2011), Developing safety indicators for preventing offshore oil and gas deepwater drilling blowouts, Safety Science, Vol. 49, n. 8-9, pp. 1187-1199.

Skogdalen, J.E. and Vinnem, J.E. (2012), Quantitative risk analysis of oil and gas drilling, using Deepwater Horizon as case study, Reliability Engineering and System Safety, Vol. 100, pp. 58-66.

Small, M.J., Stern, P.C., Bomberg, E., Christopherson, S.M., Goldstein, B.D., Israel, A.L., Jackson, R.B., Krupnick, A., Mauter, M.S. and Nash, J. (2014), Risks and risk governance in unconventional shale gas development, ACS Publications.

Smith, W.H.F. and Sandwell, D.T. (1997), Global sea floor topography from satellite altimetry and ship depth soundings, Science, Vol. 277, pp. 1956-1962. 
Song, Y. and Haidvogel, D.B. (1994), A Semi-implicit Ocean Circulation Model Using a Generalized Topography-following Coordinate System, Journal of Computational Physics, Vol. 115, pp. 228-244.

Stramma, L. and England, M. (1999), On the water masses and mean circulation of the South Atlantic Ocean, Journal of Geophysical Research, Vol. 104, pp. 20863-20883.

Teal, J.M. and Howarth, R.W. (1984), Oil spill studies: a review of ecological effects, Environmental Management, Vol. 8, n. 1, pp. 27-43.

Topham, D. (1984), The formation of gas hydrates on bubbles of hydrocarbon gases rising in seawater, Chemical Engineering Science, Vol. 39, pp. 821-828.

Ugochukwu, C.N.C. and Ertel, J. (2008), Negative impacts of oil exploration on biodiversity management in the Niger De area of Nigeria, Impact Assessment and Project Appraisal, Vol. 26, n. 2, pp. 139-147.

U.S. Department of Energy, (U.S. DOE) (1999), Environmental benefits of advanced oil and gas exploration and production technology, 168p.

U.S. Energy Information Administration (U.S. EIA) (1998), Future Supply Potential of Natural Gas Hydrates, Report DOE/EIA-0484, pp. 73-90.

U.S. National Ocean Industries Association (U.S. NOIA) (2005), What are environmental challenges and regulatory barriers to expanding our natural gas supply and how can they be remedied?, in Natural Gas Conference, Senate Energy and Natural Resources Committee, pp. 9-11.

Wang, Y. (2004), Ocean Tide Modeling in the Southern Ocean, Technical Report 471, Department of Civil and Environmental Engineering and Geodetic Science, The Ohio State University, Columbus, Ohio.

Yapa, P.D. and Zheng, L. (1997), Simulation of oil spills from underwater accidents I: Model development, Journal of Hydraulic Research, Vol. 35, pp. 673-688.

Yapa, P.D., Zheng, L. and Chen, F. (2001), A model for deep-water oil/gas blowouts, Marine Pollution Bulletin, Vol. 43, pp. 234-241.

Zheng, L. and Yapa, P.D. (1998), Simulation of oil spills from underwater accidents II: Model verification, Journal of Hydraulic Research, Vol. 36, pp. 117-134.

Zheng, L. and Yapa, P.D. (2000), Buoyant velocity of spherical and nonspherical bubbles/droplets, Journal of Hydraulic Engineering, Vol. 126, pp. 852-854.

Zheng, L. and Yapa, P.D. (2002), Modeling gas dissolution in deep-water oil/gas spills, Journal of Marine Systems, Vol. 31, pp. 299-309. 